\title{
READERS
}

Journal of Management Info (JMI)

ISSN:2313-3376

www.readersinsight.net/jmi

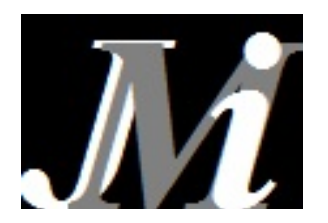

\section{Reconstruction of ethnic identityamong bugis community in Pontian Johor}

\author{
Andi Adijah ${ }^{1}$. Rosman Md Yusoff ${ }^{2}$, Mohd Koharuddin Mohd Balwi ${ }^{1}$, Tariq ${ }^{3}$ \\ ${ }^{1}$ Faculty of Management, University Technology Malaysia, Skudai 81310, Johor Bahru \\ ${ }^{2}$ Professor, University of Tun Husain Onn Malaysia \\ ${ }^{3}$ Language Academy Faculty of Management, University Technology Malaysia, Skudai 81310, Johor Bahru \\ ${ }^{*}$ Corresponding author:
}

\begin{abstract}
This study focuses on the Bugis ethnic identity and retention efforts, among the Bugis community in Pontian, Johor. This study used qualitative methods with ethnographic approach through semistructured interviews, moderate participant observation and documentation. Data was analyzed using NVivo 8 software to assist in the process of transcription and data organization. NVivo 8 generated data analysis has been prepared based on coding, themes, order and categories. The entire data has been organized, checked using triangulation data technique and time. The results show that the Bugis ethnic identity which is still practiced in Pontian until now is a form of Bugis nonmaterial culture. While maintaining the identity of the efforts made by individuals and groups by way of inheritance of cultural values through the filtering process of filtering elements of culture which are based on Islam, adaptation to local culture and government policy.
\end{abstract}

\section{ARTICLE INFORMATION}

$\begin{array}{ll}\text { Received: } & 25 \text { March } 2017 \\ \text { Revised: } & 25 \text { April } 2017\end{array}$

Accepted: 25 June 2017

DOI:

http://dx.doi.org//10.31580/jmi.v5i1.36

\section{Introduction}

Since ancient time known as ethnic Bugis people who had the habit of travels and trade (Sompe). According Ammarell (2002) wandering Bugis is characterized as searching for good fortune, luck or for a better life, in Bugis called massappa dalle . Massapa dalle efforts (seek). This is a habit that is related to entrepreneurial Bugis culture. Bugis colony is not only due to the economic problems but also of the political problems. The chaos on the Bugis land (now South Sulawesi Province, Indonesia) causing them to leave the land of their birth. Another factor is the desire of the soul Bugis itself, namely encouragement philosophical, meaning of life associated with the freedom and encouragement as traders, Kesuma (2004).

Bugis ethnic identity has been record by various European explorers (Portuguese, Dutch and English), hence centuries ago, as revealed by Tome Pires Bugis traders who had met when visiting Melaka in 1512 (Cortesao, 1944) and JR Logan, who also met with Bugis traders on the island of Penang in 1830 (Logan, 1851). These notes were written by Cortesao Pires (1944) in a book entitled "The Suma Oriental of Tome Pires and The Book of Francisco Rodrigues". Pires described in the notes the identities of Bugis either in character or appearance. In terms of character Bugis traders have the skill in managing a business, dealing honestly, independent and virtuous, brave and capable of dealing with high effort (Cortesao, 1944; Leith, 1805). In terms of physical stature they have strong energy as described by Pires that the stature of the Bugis has a robust physique, strong, handsome, like a hero and speak Bugis Language. All this has made the Bugis traders respectable among European traders (Cortesao, 1944; Logan, 1851). Pires added that Bugis have exemplary character and their ancestral figures embedded in their psyche. Among them is the "Sawerigading", Bugis warrior persona is recorded in a long saga called Lontara I Lagaligo (Kern, 1993). Which is written in Lontara provide guidance on how to build a life in the land of wandering. The other thing is the cultural identity of Bugis, about the Bugis concept, siri and pesse (Moh. Yahaya Mustafa, 2003; Pimentel, 1981). Both of these concepts have breathed moral strength into traders in foreign sailors. The concept of the siri is associated with shame, self-esteem or dignity. An example is siri that will feel it necessary to uphold the rights that have been usurped. These siri are always upheld by the Bugis and confirmed by a principle, "better to die in defending siri, compared to the life I hadn't a siri". While the concept pesse closely related to the strength of the bond of brotherhood to strengthen community ties. Bugis tradition illustrates the importance of the spirit of collaboration in building a life. The concept of the siri and pesse have become a way of life for immigrants Bugis traders, so that they become a respectable dealer and admired by other trader as well as to strengthen the spirit and dominate trade relations.

Bugis migration to Johor started at about the 17th century (Raja Ali, 1982; Vos, 1993; Andaya, 1975), and continues until today. Based on the results of population census Indonesia in $2000-2010$, Bugis people who inhabited the region a total of 5,157,000 Indonesia (BPS, 2003), while the Bugis people who inhabited the region a total of 728.465 Malaysia (BPS, 2003), of which there are 60,000 people living in Johor (Kesuma, 2004 ), and most of them come from Wajo (Kesuma, 2004; Khazin, et al., 2009). While the Bugis people residing in the state of Johor most of them living in Pontian District (Md. Sah \& Sahrul, 2011).

Bugis people who migrated to Johor, especially to the District of Pontian, also brought their identity and cultural values, whether material culture or non-material culture. At the beginning of their arrival, they were able to maintain their culture, because they came 
forth, mingled and married only to their fellow Bugis. But what happens in the face of changing times, culture once practiced is now increasingly fading. It can be seen mostly in younger Bugis generation, intermixing with the customs of their culture and way of local life (Halimah, 1980). Their Bugis identity is no longer more visible than that of other communities. Behavior of Bugis people, first as revealed by European explorers (Cortesao, 1944; Leith, 1805; Logan, 1851) is no longer visible. Similarly, the material culture of Bugis, today has been eroded, their remains stored only in Bugis Museum in Teluk Kerang, Pontian, and exists only in certain people. This is because there is no longer Bugis people who can make things such as special weaving Bugis (silk dress/baju bodo, silk sarung), Bugis traditional tools (badik, kawali), Bugis houses, boats etc. Even skill in making Bugis food like Burasak, cultural values siri and pesse, and Bugis language, which is regarded as essential to identity formation Bugis in Malaysia, practiced only by ethnic old Bugis people. Accordingly, the study of identity preservation is considered essential for the existence of consciousness and responsibility for the conservation of the cultural treasures of the archipelago and to assist communities in rebuilding the identity of Bugis and kebugisan amid these trying times.

\section{Research methodology}

This research explores the process of Bugis identity to comprehend the problems of ethnic identity in greater detail. Therefore in this study used qualitative methods to understand the phenomenon in a holistic manner with natural background about the process of reconstruction the identity of the Bugis and kebugisan that has been neglected by the proponents of this culture. An ethnographic approach is used in this study to investigate cultural groups in natural environments (Creswell, 2007). In this study, the researcher is the main instrument and plays the role of interpreter continuously. The implications of this research are constructivist-interpretive which researchers try to understand the construction of reality based phenomenon, knowledge, attitudes and values that exist in the real world experience (Crotty, 1998; Yeap, 2000; Denzin \& Lincoln, 2003; Sugiyono, 2006; Levy, 2006; Bryman, 2007; Creswell, 2009; Schwandt, 2009).

\section{Sampling}

Samples were selected based on non-probability sample and aims (purposive sampling). This technique is intended for a specific purpose so as to focus on a target and not done in the whole population (Patton, 2002; terrian, 2002; Gay, et al., 2006; Wilson, Van Voorhis \& Morgan, 2007; Creswell, 2008; Given, 2008; Semaan, 2010; Sugiyono, 2011). The goal of this sampling pusposive is to improve the usefulness (utility) of information obtained from small samples, subjects were selected based social phenomena owned. The selected sample is Bugis, Bugis or descent living in Pontian, Johor, with livelihoods in agriculture and business for example in the types of businesses: food stores, grocery stores, clothing stores, coconut and oil palm farming, processing and sale of food or drink, laundry, home stay (homestay), and contractor services. Selected samples in this study were 16 people from the area: Kukup, Ayer Baloi, Pekan Nanas and Benut.

\section{Method of data collection}

Data collection methods used interviews, observation and documentation. Type of interview used in this study follow the recommendations (Othman Lebar, 2007) is a semi-structured, which is basically an opportunity for respondents to be more open in disclosing ideas and opinions. The first step to do is to build an open question, which means that responses can be developed by the respondents. Type the observations made by (Sugiyono, 2011), namely participation in moderation, arguing that researchers play a balanced role as insiders and as an outsider. In the process of collecting information, researching perform various roles in activities among Bugis community, but not all, for example to check the activities of daily family life of respondents, following a meeting which was founded by a group, such as the Association of the State of Johor Bugis (OGI). While the methods used to support the documentation and information to deeply understand the identity of Bugis. Therefore, used various documents collected before, during and after conducting research in the study area. Collected documents include letters, census data, diaries, family archives of Bugis culture and family history.

\section{Data analysis}

To get the reliability and validity of the instrument, the researcher first conducted a pilot study. Interview protocol was built on the results of the pilot study and results of the discussion in "peer group", hence improvement before the actual interview sessions was made. While data analysis used in this study is NVivo 8 software to assist the transcription of data and organize the data by coding and theme. The process of data analysis was performed by continuous, as proposed by (Othman Lebar, 2007), which is associated with the examination of the meaning of words and actions. After each interview, data analysis, coding and grouping in a pattern emerging themes were done. Furthermore, we also performed a comparison between the findings with other findings. The obtained saturated data of interview were discarded.

Triangulation is used to identify different reality, it can reduce misinterpretations and describes the challenging procedures in qualitative research (Stake, 2005). This study was done in three ways, namely triangulation: source triangulation, technique triangulation and time triangulation. The latter process is the presentation of data. Presentation of data is compiling information that can give the possibility to conclude and implement action. The qualitative data were presented in the form of narrative text of the note field and shaped matrix.

\section{Type of bugis culture in Pontian}

The findings of this study indicate that there is some kind of Bugis culture that is still practiced in Pontian. This type of culture is focused on non-material culture (not shaped objects or material). According to the opinions of Tersptra and Sarathy (2000) that cultural elements consist of 8 , ie language, religion, values and attitudes, education, social organization, law and politics, aesthetics, as well as technology and material culture. Between 8 elements of the culture, there are only 5 (five) elements Bugis culture that remain in Pontian until today, namely language, religion, values and attitudes, social organizations and some aesthetic elements. There are three elements that have been left out of the law and politics, education, and technology and material culture, this is because the process of adaptation and filtering of culture. For example in the technology, known in his native country Bugis very clever in making technology sailboats, weave silk fabric, but in Pontian, none found Bugis people who can make a sailboat and weave silk fabric. Most Bugis people are found in Pontian conducting economic activities in business and agriculture; in addition, a of Bugis work as civil servants. The manufacturing technology of sailboats and weave silk fabric were abandoned because the tools and materials were difficult to find.

Some types of the Bugis culture are found in the form of values (values) of reso (effort or hard work), siri (shame or self-esteem), lempu (honesty). The findings of this study are consistent with the findings of Kinseng \& Saharuddin (2009), Amarel (2002), Acciaioli (2000) who find some kinds of Bugis culture which is still practiced, commenting on their migration and destinations. Research of Kinseng \& Saharuddin (2009) discovered the existence of the reso (hard work) in Bugis fishermen who migrated to East Kalimantan, Jambi, Bali and Banten. Acciaioli (2000) found the existence of Bugis Customs in Bugis language called Ade, in one destination to which Bugis migrated, Lindu Lake, Sulawesi Tengah. While Ammarel (2002) who conducted a study on Bugis migrants in East Timor, West Timor, Maluku, Central Sulawesi and West Papua also found the reso (effort or hard work) is still practiced by Bugis migrants.

Among the non-material cultural elements that are often found in Bugis community in Pontian is customary marriages. Indigenous 
choose a mate based on parental choice. All matters of marriage partner is managed by family members. Custom wedding Bugis society is considered superior to marriage with kin, it is encouraged, so that the selection of partner sought from immediate family (Mattulada, 1995). There are three types of marriages, which are encouraged. They are as follow, (1) assialang marola, means marriage between first cousins either maternal or paternal, (2) assialanna memeng, marriage between brother and two cousins either from maternal or paternal side, (3) rifaddeppe mabelae, means a much closer marriage between third cousins either from maternal or paternal side. People comment on the Pontian customary wedding practice (Bugis), as to avoid the collapse of the family and to arrest the property from falling into others' hands. Marriage system is intended to ensure the property that it does not fall to another person, in addition to maintaining the status and position (Koentjaraningrat, 1993). Status and position in question is peerage inherited from their ancestors. This status is derived from the paternal lineage (patriliner). Among these titles are Andik, Daeng, Ambok, Indok, Basok, Bessek. Indirectly customary marriage is one such effort Bugis try to retain its identity.

Results of interviews and observations found that non-material cultural elements still remain among the Bugis in Pontian. Bugis language (Ogi language) spoken by the Bugis community symbolize their personalities. Sometimes they use symbolic language to avoid speech that is considered impolite. Some respondents gave examples of symbolic Bugis language, for example if someone wants to express the death of a king, "the king who died on the mountain", they would say, "Arungnge Matinroe ri bulue", means the king who slept on the mountain. This means that the word "sleep" in Bugis considered more polite and respectful than the word "die". In conclusion, higher the courtesy, respectable is the crowd.

In fact, it appears that Bugis' non-material culture practice in Pontian is not according to the Bugis original culture practice, carried out by Bugis community in South Sulawesi (Indonesia). For example, Bugis' marriage customs are no longer entirely based on partner choice among kinsfolk alone, but there has been some intermarriage between ethnic groups. While the Bugis language dialect spoken in Pontian dialect is no longer exists in the language of Bugis, living in South Sulawesi, but influenced by the dialect of Malay language. Similarly, the values on which Bugis' culture is based as well as some habits are no longer used because it is considered contrary to Islamic teaching, Malay culture and government policies, such as killing someone for enforcing siri (self-esteem or dignity). Hence, it can be said that the practice of non-material culture of Bugis in Pontian have undergone a process of adaptation or adjustment to the local culture in Pontian. This supports the view Mude et al., (2009) explain that the culture that brought by Bugis community into the area of adaptable region was accepted by the local community as a cultural region, Bugis have universal properties that can coexist with the local culture to where Bugis people migrated.

\section{Adaptation and inheritance of cultural values bugis}

Adaptation and succession process of cultural values are two key elements used in Pontian Bugis community to maintain and rebuild their ethnic identity. Adaptation is a key issue that must be faced by migrants including Bugis Migrants in their new location. The findings of this study indicate that there has been a process of adaptation and inheritance of cultural values among the Bugis community in Pontian. Based on the results of interviews with respondents, Bugis cultural adaptation in Pontian was more focused on language and customs. Bugis language used in everyday conversation in Pontian, is no longer the same as it used to be, (the original Bugis language) but tend to use a dialect of the Malay language and adopted few words from Malay language. The findings of this study support the findings Abdul Latif Ahmad et al (2014) that explore intercultural adaptation process Malaysian students in the UK and Australia, where respondents concerned to adjustment of languages.

Similarly, the customs, Bugis community practice in Pontian are some Bugis' indigenous practices, and some Malay customs. An example is of customary marriage, Bugis culture weddings party made in collaboration, known as rewang. The whole family will be coming to help organize the wedding party, starting from the preparation of the event, decorating the house, making meals and some other things. Results of the interviews and observations still find this habit in Bugis community in Pontian. Likewise, using traditional Bugis also use Malay customs, such as berinai and garment used by indigenous Malay wedding. They have not yet adopted the baju bodo (Bugis traditional dress for bride) and sigera (Bugis traditional attire for groom). Using both cultures reflect cultural adaptation process already occurred, such as, the concept of adaptation highlighted by Constantin, Okazaki and Utsey (2004) that the intercultural adaptation occurs while individuals or groups can understand and explore new cultures and try to merge with the new culture with values of their lives.

The results show that four easy ways were considered in the process of devolution of cultural values, namely, (1) provide information orally, (2) give the examplary, (3) entered the race within a family, such as a race speaking in the family, (4) hold a meeting to discuss about Bugis culture. These findings are consistent with the studies of Kermally (2002), which give a detailed account of the transfer process of cultural values through discussions, conversations, dialogues and meetings. However, these findings differ with some of the results of past studies (Drucker, 1994; Ching and Jie, 2000; Bender and Fish, 2000; Milner, 2000; Stacey, 2003; Yakhlef, 2005) studies found that ICT (Information, Communication and Technology) is an easy way to transfer knowledge. The difference is due to differences in emphasis in the way of knowledge transfer. This study concerned the method used in the process of transfer of cultural values, but past studies on caring for facilitators and facilitation of knowledge transfer

Even the results of this study show that respondents who serves as senders in practice transferred these cultural values, culture obtained from their parents, then reinforced with experience in daily activities. This process requires a long apprenticeship from childhood up to the present, it also confirms the findings of Allee (1997) and Ching Chyi Lee and Jie Yang (2000) who say that tacit knowledge in this regard are cultural values, cannot be described or explained, but by way of apprenticeship may be transferred or inherited. After building one's own family, even this cultural transfer process continues up to a generation, either intentional or unintentional. Respondents admitted that it was difficult to express culture in words, numbers or symbols. However, this time there have been attempts to move the formal knowledge of the culture, for example by creating program that discuss about Bugis culture. Researchers have been conducting observations and found that the people of Bugis in Pontian, Johor particularly are aware of how important transfer Bugis culture to the present generation, the community formed a group called Association of Bugis of the Johor State and has branches in several areas under the state of Johor. These groups always hold assemblies to discuss Bugis' culture.

The opinions of some of the respondents said, in fact it cannot be denied that there is some kind of Bugis' culture that has characteristics contrary to Islam, though Muslim Bugis have developed an assumption that being Bugis as a Muslim. This finding supports the view of Mohd. Taib Osman (1989), Abdullah Ishak (1992), Mohd. Abu Bakar (2005), that Islam brings changes, but that contradict Islamic traditions, is still thriving. Mohd. Abu Bakar (2005) adds, among the Malays, Islam as the dominant culture has not succeeded beyond the frame of length. The matter, encouraging dialogues among the stakeholders to carry out screening cultures outside the entrance of the archipelago. But, most respondents agreed that cultural Bugis have adopted culture in Pontian that is in line with Islam. Such as, Reso (hard work), siri (shame or self-esteem) and lempu (honesty), valued by slam. While foreign cultures come into the archipelago is considered to be in conflict with the teachings of Islam, the culture will not be applied. These cultures will undergo a process of filtering or screening using Islam as a basis for screening, for example the council or office constantly monitor if there is anything that contradicts Islam. Islamic syara, is a filter for the formation of a new culture and society. This filtering process make 
the teachings of Islam as a guideline for cleaning up the culture containing illegal things, then build a new superior culture.

Re-using culture can support the retention of that culture. When a culture has never been practiced then it will soon become extinct. So, this modern time demands retention of cultural heritage so it can be enjoyed and appreciated by future generations. The efforts made by Bugis community in Pontian to maintain Bugis culture are the participation of individuals, families and communities for cultural transfer in circles. This finding is consistent with the view of Ong Chao Liu et. al., (2010), who say that retention efforts should be made from the very basic level in various ways, including through the participation of individuals and communities. The observation shows that cultural preservation efforts of Bugis in Pontian are more done by individuals in a family. But there is also a community founded by Bugis Society in Johor State. Bugis cultural preservation efforts are available individually, performed by an entrepreneur who founded the museum Bugis in Teluk Kerang, Pontian. The museum has been recognized by the Johor state government as the Bugis people who appreciate culture has become a cornerstone in the development of the country especially in Pontian. Other individual effort is made Bugis wedding festival, home stay development with custom nuanced Bugis, a consultant for the Bugis culture with the presentation of papers in various cultural assemblies.

Business community founded by Bugis Association Johor, have regular meetings and various activities involving the Bugis community, since its inception in 2007 until now. First this association held most commercial activities to enhance economic Bugis society, such as the establishment of cooperative Bugis, courses in business. However, subsequent developments affected the activities performed to maintenance Bugis culture, such as religious sermons in Bugis, Bugis harp performances, even designed a program of Bugis language courses. In addition, the government is also supporting the retention of Bugis culture for example by providing funds for various activities related to Bugis cultural preservation.

Finally, the overall results of the study show that Bugis' culture has passed down from the past generation to the present generation and undergone a process of filtering based on the Islam, the adjustment to the culture environment and government policy. Implications practice Bugis cultural values such as driving or spirit of the Bugis community in Pontian to improve the quality of their lives. However, Bugis culture has helped shape, brighten and enrich the cultural treasures in this multi-ethnic government.

\section{Conclusion}

Overall, this study was able to achieve its objectives and has provided added value to the efforts of preservation of cultural identity. This study has successfully identified the types of Bugis culture maintained in Pontian. Where necessary adapt and integrate with the culture and environment of government policy through the filtering process. The study also reveals the efforts undertaken by individuals and communities Bugis to maintain their traditional culture. Individuals in the family (source) to transfer (transmit) cultural values to the next generation (receiver) through informal education by teaching oral and set an example. Individuals outside the family transfer of cultural values to others through the documentation of traditional cultural relics such as Bugis building of the museum presented a paper on Bugis culture at various assemblies that discuss culture. While the Bugis community founded by Bugis Association of Johor holds periodic meetings aimes at fostering friendship among the Bugis community and to discuss continuation of Bugis culture.

\section{Refrences}

Abdul Latif Ahmad, Nur Zalila Md Zamri, Ali Salman, Emma Mirza Wati Mohamed \& Hasrul Hashim. (2014). Isu-isu dan Masalah Adaptasi Antara Budaya dalam Kalangan Pelajar Malaysia di United Kingdom dan Australia. Journal of Social Sciences and Humanities. Vol.9. No. 2 (2014) 162-171, ISSN: 1823-884x

Abdullah Ishak. (1992). Islam di Nusantara: Khususnya di Tanah Melayu. Kuala Lumpur: Bahagian Hal Ehwal Islam.
Acciaioli, G. L. (2000). Kinship and Debt: The Social Organization of Bugis Migration and Fish Marketing at Laku Lindu, Central Sulawesi. Bijdragen Tot De Tall, Land En Volkenkunde 156(3): 589-617.

Allee, V. (1997). The Knowledge Evolution: Expanding Organizational Intelligence. Washington Street, USA: Butterworth-Heinemann.

Ammarel, G. (2002). Bugis Migration and Modes of Adaptation to Local Situations. Journal Ethnology. Vol 41. No. 1. 52.

Andaya, L.Y. (1975). The Kingdom of Pontian, 1641-1728. Kuala Lumpur: Oxford University Press.

Andaya, L.N. (1981). The Heritage of Arung Palakka: A History of South Sulawesi (Celebes) in the 17th Century. The Hague: Martinus Nijhoff.

Badan Pusat Statistik (BPS). (2003). Penduduk Sulawesi Selatan (Hasil Sensus Penduduk Tahun 2000). Jakarta: BPS.

Bender, S. Dan Fish, A. (2000). The Transfer of Knowledge and the Retention of Expertise: the Continuing Need for Global Assignment. Journal of Knowledge Management. 4(2): 125-137.

Bryman, A. (2007). Qualitative Research 2 Volume 1. Thousand Oaks, California: SAGE Publications Inc.

Ching Chyi Lee \& Jie, Yang. (2000). Knowledge Value Chain. Journal of Management Development. 19(9): 783:793.

Cortesao, A. (1944). The Suma Oriental of Tome Pires and The Book of Fransisco Rodrigues. London: Halkyut Society.

Constantine, M. G., Okazaki, S.,\& Utsey, S. O. (2004). Self-Concealment, Social Self-Efficay Acculturative Stress, and Depression in African, Asian and Latin American International College Students. American Journal of Orthopsychiatry, 74: 230-241.

Creswell, J.W. (2007). Qualitative Inquiry and Research Design: Choosing among Five Approaches (3rd ed.). Thousand Oaks, CA: SAGE Publications.

Creswell, J.W. (2008). Educational Research: Planning, Conducting, and Evaluating Quantitative and Qualitative Research. New Jersey: Pearson Prentice Hall.

Creswell, J.W. (2009). Qualitative, Quantitative, and Mixed Methods Approaches. Thousand Oaks, CA: SAGE Publications.

Crotty, M. (1998). The Fondations of Social Reseach: Meaning and Persfective in the Research Process. London: SAGE.

Denzin, N. K., \& Lincoln, Y. S. (2003). The Landscape of Qualitative Research: Theories and Issues Second Edition. In N. K. Denzin \& Y. S. Lincoln (Eds.) Thousand Oaks, CA: Sage Publications, Inc.

Drucker, P.F. (1993). Post Capitalist Society. Oxford: ButterworthHeinemann.

Gay, L.R., Milss, G.E., \& Airasian, P. (2006). Educational Research: Competencies for Analysis and Applications. New Jersey: Pearson Prentice Hall.

Given, L. M. (2008). The Sage Encyclopedia of Qualitative Research Methods (Vol. 2). Thousand Oaks, CA: Sage Publications Inc.

Halimah Bt. Haji Omar. (1980). Orang-Orang Bugis di Pontian: Kajian dari Segi Kegiatan di dalam Bidang politik, Sosial dan Ekonomi antara tahun 1900-1967. Latihan Ilmiah. Bangi: Jabatan Sejarah Universiti Kebangsaan Malaysia

Kermally, S. (2002). Effective Knowledge Management: A Best Practice Blueprint by Sultan Kermally. US: Wiley \& Sons, Incorporated, John.

Kern, R. A. (1993). I Lagaligo. Yogyakarta: Gadjah Mada University Press

Kesuma, A.I. (2004). Migrasi dan Orang Bugis. Jogjakarta: Ombak.

Kinseng, R.A., \& Saharuddin. (2009). Pola Penyebaran dan Mobilitas Sosial Nelayan Bugis di Indonesia. Prosiding Hasil-hasil Penelitian IPB 2009. Bogor: Institut Pertanian Bogor.

Khazin Moh Tamrin, Nordin Hussin, Nelmawarni, \& Rahilah Omar. (2009). Sejarah Kedatangan masyarakat Bugis di Tanah Melayu: Kajian Kes di Pontian. Malaysian Journal of History, Politics and Strategic Studies. 36. pp 41-61.

Koentjaraningrat. (2004). Pengantar Antropologi. Jakarta: Aksara Baru.

Leith, G. (1805). A Short Account of the Settlement, Produce and Commerce of Prince of Wales Islands in Straits of Melaka. London: J. Booth.

Levy, D. (2006). Qualitative Methodology and Grounded Theory in Property Research. Pacific Rim Property Research Journal, Vol. 12, No. 4, pp. 369388.

Logan. J. R. (1851). Notices of Penang. Journal of Indian Archipelago. 5: 1$14,53-65$.

Mattulada. (1995). Latoa: Suatu Lukisan Analitis terhadap Antropologi Politik Orang Bugis. Ujung Pandang: Hasanuddin University Press.

Md. Sah bin Daeng Mattatah \& Syahrul Amin Syah bin Md. Sah. (2011). Sejarah Ringkas Penglibatan Orang Bugis di Semenanjung Tanah Melayu dan Penempatan Tradisional Masyarakat Bugis di Negeri Pontian. Proceeding International Convention Bugis Diaspora. Pusat Kajian Alam Bina Dunia Melayu. Pontian Darul Ta'zim: University Teknologi Malaysia.

Merriam, S.B. (2002). Qualitative Research In Practice. San Fransisco, Calif: Jossey Bass. 
Milner, E. M. (2000). Managing Information and Knowledge In the Public Sector. New York: Routledge.

Moh. Yahaya Mustafa. (2003). Siri dan Pesse Harga Diri Orang Bugis, Makassar, Mandar, Toraja. Makassar: Pustaka Refleksi.

Mohd. Abu Bakar. (2005). Islam sebagai Budaya dan Peradaban dimana, ke mana? Majalah Pemikir 39 dan 40, Jan - April - Jun, halaman: 271-282.

Mohd. Taib Osman. (1989). Malay folk beliefs an Integration of Disparate Elements. Kuala Lumpur: Dewan Bahasa dan Pustaka.

Mude, M.S., Malla, A.B., Atma, A., Nawawi, A.M., \& Hartono, R. (2009). Bugis di Tanah Rantau. Jakarta Timur: Focus Grahamedia.

Ong Puay Liu, Nur Hafizah Yusoff \& Sharina Abdul Halim. (2010). Menjejak Semangat 'Kawi': Langkawi sebagai Geopark. Akademika : 55-68.

Othman Lebar. (2007). Penyelidikan Kualitatif Pengenalan kepada Teori dan Metod. Tanjong Malim: Penerbit Universiti Pendidikan Sultan Idris.

Patton, M. Q. (2002). Qualitative research and evaluation methods (3rd ed.). Thousand Oaks, CA: Sage Publications, Inc.

Raja Ali Haji. (1982). Thufat Al-Nafis: The Precious Gift. Kuala Lumpur: Oxford University Press.

Schwandt, T.A. (2009). Pendekatan Konstruktivis-Interpretivis dalam Penelitian Manusia. In N. K. Denzin \& Y. S. Lincoln (Eds.), Handbook of Qualitative Research (Translate). Yogyakarta: Pustaka Pelajar.

Semaan, S. (2010). Time-Space Sampling and Respondent-Driven Sampling with Hard-To-Reach Populations. Methodological Innovations Online, $5(2), 60-75$.
Stacey, R. D. (2003). Strategic Management and Organisational Dynamics: The Challenge of Complexity. London, UK: Pearson Education Limited.

Stake, R. E. (2005). Qualitative Case Study. In N. K. Denzin \& Y. S. Lincoln (Eds.), The Sage Handbook of Qualitative Research (Vol. 3, pp. 443-466). Thousand Oaks, CA: SAGE Publications.

Sugiyono. (2006). Metode Penelitian Kuantitatif, Kualitatif, dan R\&D. Bandung: CV. Alfabeta.

Sugiyono. (2011). Metode Penelitian Kombinasi (Mixed Methods). Bandung: Alfabeta.

Terpstra, V. \& Sarathy, R. (2000). International Marketing, 8th Edition. Dry Den Press.

Vos, R. (1993). Gentle Janus: Merchant Prince. Leiden: KITLV.

Wilson, C.R., Van Voorhis \& Morgan, B.L. (2007). Understanding Power and Rules of Thumb for Determining Sample Sizes. Tutorials in Quantitative Methods for Psychology, Vol. 3 (2), pp. 43-50.

Yakhlef, A. (2005). Immobility of Tacit Knowledge and the Dispalacement of the Locus of Innovation. European Journal of Innovation Management. 8(3): 118-126.

Yeap, K.L. (2000). Kajian Kualitatif: Suatu Pengenalan. Essai Penyelidikan. Jurnal Keningau Bil. 3. 